\title{
Cognitive Apprenticeship Improves Self Efficacy At Aviation Polytechnic Of Surabaya
}

\author{
Setiyo, Yatim Riyanto, Luthfiyah Nurlaela \\ Teknologi Pendidikan, Pascasarjana, Universitas Negeri Surabaya, Indonesia \\ setiyo.mhs@unesa.ac.id
}

\begin{abstract}
Internships are a method of connecting learning in schools with actual work powered by experts in the field of work. Self-efficacy skills are very necessary in the world of work. Self efficacy is, a person's belief in carried out their duties. The research purpose determined the effect of cognitive apprenticeship on students self efficacy in Flight Polytechnics. The research method used ANOVA with the experimental and control groups, with 140 research subjects. The results showed the influence of cognitive apprenticeship on self efficacy. Self-efficacy ability is needed in the world of work, because it relates to one's success in doing work. Vocational education aims to prepare a skilled workforce. Internships are a means to bring students closer to the world of work. Soft skills in vocational education must be developed. The apprentice is able to bring the development of soft skills to students. Workers with self-efficacy skills are needed in the industrial era.
\end{abstract}

Keywords: Cognitive apprenticeship, self efficacy, vocational education.

\section{Introduction}

Vocational education aims to form an expert workforce, also directed at soft skills, and problem solving adapted to the world of work. Internships that have been carried out so far, are still not aligned with the expectations of vocational education goals that are in accordance with the demands of the world of work. The internship activities are expected to be able to develop problem solving skills, soft skills, and the ability to think. The implementation of an internship should be able to harmonize the knowledge and skills that have been obtained in the academy with the world of work. Internships must be designed to be a learning environment in a social context with real tasks guided by experts as partners, and strived for competency and cognitive skills in accordance with real problems (Gessler, 2009). Cognitive apprenticeship is a method that brings students closer to the actual work. Collins, et al. (1987) in Dennen \& Burner (2008) define cognitive apprenticeship, namely learning through guided experience in cognitive and metacognitive abilities, not physical, and process. Willemsen \& Gainen (1995) recommends cognitive apprenticeship after comparing with seven models of active learning that because this model uses the apprenticeship metaphor of learning skills, where students are not as subjects, to understand the development of a skill. The cognitive apprenticeship method is faced in everyday situations which are rich learning resources where students become part of the community by observing, practicing, and getting help with community activities.

The cognitive apprenticeship method is designed to bring the tacit process (knowledge transfer) indirectly openly, where students can carry out observational activities, enact (implement), and practice with the help of learners and other learners (Collins, 1987). The development of self-ability in vocational education is the main thing. This is related to the interpersonal and soft skills of students in the world of work. Self efficacy is a proven construct of motivation influence choice of individual activities, level of goals, perseverance and performance in various contexts (Zhao, Seibert, \& Hills, 2005). Maritz \& Brown (2013) showed the results of self-efficacy studies that showed consistent findings, such as have proven relationships with performance and work, including sales of life insurance, productivity of lecturer, research, facing difficult career-related tasks, learning and achievement (Wood and Locke 1987) and the ability to adapt to new technologies. Self efficacy is related to the achievement of academic goals (Wood \& Locke, 1987). Some studies have found self-efficacy to be a better predictor of subsequent performance than past behavior (Gist, 1987). Self efficacy has a strong influence on the achievement of one's academic goals and performance. Since self efficacy has three dimensions, namely magnitude apply to the level of difficulty of the task that one believes he can achieve, a force that refers to strong, weak beliefs and generally shows the extent to which expectations are common in all situations (Bandura, A. 1977). Ramey-Gassert, Shroyer, \& Staver (1996) explain that self efficacy influences job satisfaction. 


\section{Method}

The research subjects were students at Aviation Polytechnic totaling 140 students. Research time was 5 months. Self efficacy influences the training process (Davis, Fedor, Parsons, \& Herold, 2000). The data analysis technique used ANOVA. The procedure for conducting the research was that the research subjects were divided into two groups, cognitive apprenticeship and on-the job training. Research subjects carry out internships at airports that are spread throughout Indonesia that are in accordance with their fields of expertise.

\section{Results and Discussion}

Cognitive apprenticeship shows that there is a positive influence on the self efficacy of students at Aviation Polytechnic in Surabaya. Self efficacy is self-confidence based on self-assessment relating to one's competence in carrying out their duties. In the cognitive apprenticeship, students are given the widest opportunity to solve problems they face in work practices in accordance with their competencies. In implementing cognitive apprenticeship, students face the real situation where they are part of it, so that they are directly involved. Self efficacy is formed through the environment, where the positive environment can increase self efficacy. A positive environment can improve self-capability. In implementing cognitive apprenticeship, students are faced with the actual work environment by solving problems in their field of work. Students are able to study well because they have good beliefs because they are in accordance with their abilities. In cognitive apprenticeships, students are given the freedom to solve problems encountered in worker training, thus giving rise to confidence. Field instructors act as facilitators and guides (coaching) if students need help. Students with cognitive apprenticeships are given the freedom to use various strategies (heuristic strategies) in their work training process. Then the students control the strategy that used in the problem solving process by reflecting on the processes that have been carried out (Darabi, 2005). In the cognitive apprenticeship model, cognitive scaffolding is directed at encouraging performance independently by reducing assistance to students so that their skills, increase (Willemsen \& Gainen, 1995) so as to increase self efficacy.

Scaffolding makes students more active and productive in a variety of learning environments, and with Scaffolding the distribution of the availability of various material and social tools with various abilities to support students in developing ways of various disciplines of knowing, doing and communicating (Reiser \& Tabak, 2014). Therefore students would start to be independent and the instructor would reduce their role in solving problems. Self efficacy affects one's performance and will increase when observing someone who is considered to have the same ability to perform tasks successfully (Wolf, 1997). Students when does work training with cognitive apprenticeship they are given flexibility in work practice, seeing friends succeed in completing tasks, the others have more trust in being able to complete tasks well. Completion of tasks is related to achieving goals, where self efficacy is closely related to achieving goals (Potosky, 2010) and is related to expectations (Scunk, 1985). The goal of work training is to improve competence in the field that students are involved in and hope is to get a job in line with its competence. These goals and expectations make students take each internship activity seriously and confidently in carrying out their assigned tasks. Therefore, students are confident in thinking, acting, and motivated in all activities during the internship. Bandura explained that self efficacy is how someone believes in thinking, acting and feeling in all aspects of his life (Ritten, Boone, \& Rubba, 2001). Self efficacy that is owned by someone will lead to its performance (Lisbona, Palaci, Salanova, \& Frese, 2018). Cheah, Li, \& Ho (2019) explained that self efficacy is related to sustainable performance.

\section{Conclusion}

The cognitive apprenticeship method has shown an influence on student self efficacy. With self-efficacy capabilities, it is expected that they have soft skills that are useful in the job. Vocational education aims to prepare skilled workers in their fields of expertise. Internships are learning that is in the work environment in fact, where learning with experts, so students will learn faster and know the tasks that must be done when they work. The cognitive apprenticeship method is faced in everyday situations which are rich learning resources where students become part of the community by observing, practicing, and getting help with 
community activities. The implementation of an internship in vocational education must be directed at improving student attitudes. The competency of a worker is not only in knowledge and skills, but attitudes must be considered.

\section{References}

Bandura, A. (1977). Self-efficacy: Toward a unifying theory of behavioral change. Psychological Review, 84, 191-215.

Cheah, S., li, S. \& Ho, Y. P. (2019). Mutual Support, Role Breadth Self-E_cacy, and Sustainable Job Performance ofWorkers in Young Firms. Sustainability, 2-17.

Collins, A. B. (1987). Cognitive Apprenticeship: Teaching the Craft of Reading, Writing, and Mathematics. Illinois: Universty of Illinois .

Darabi, A. A. (2005). Application of Cognitive Apprenticeship Model to a Graduate Course in Performance Systems Analysis: A Case Study. ETR \& D, 49-61.

Davis, W. D., Fedor, D. B., Parsons, C. K. \& Herold, D. M. (2000). The development of self eficacy during aviation training. Journal of Organizational Behavior, 857-871.

Dennen, V. P. \& Burner, K. J. (2008). The Cognitive Apprenticeship Model in Educational Practice. In J. M. Spector, M. D. Merrill, J. v. Merrienboer, \& M. P. Driscoll, Handbook of Research on Educational Communications and Technology (3ed ed., pp. 425-440). New York: Routledge.

Gavriel, J. (2015). Cognitive apprenticeship. Education for Primary Care, 422-423.

Gessler, M. (2009). Situated Learning and Cognitive Apprenticeship. In R. Maclean, \& D. Wilson, International Handbook of Education for the Changing World of Work: Bridging Academic and Vocational Learning (pp. 1611-1625). Jerman: Springer.

Gist, M. E. (1987). Self-Efficacy: Implications for Organizational Behavior and Human Resource Management. The Academy of Management Review, 472-485 .

Lisbona, A., Palaci, F., Salanova, M. \& Frese, M. (2018). The Effects of Work Engagement and Self Efficacy on Personal Initiative and Performance. Psicothema, 89-96.

Maritz, A. \& Brown, C. R. (2013). Illuminating The Black Box of Entrepreneurship Education Programs. Education + Training, 5, 234-252.

Potosky, D. (2010). Goal Orientation, Learning Self-Efficacy, and Climate Perceptions in a Post-acquisition Corporate Context. Human Resource Development Quarterly, 273-289.

Ramey-Gassert, L., Shroyer, M. G. \& Staver, J. R. (1996). A qualitative study of factors influencing science teaching self-efficacy of elementary level teachers. Science Education, 283-315.

Reiser, B. J. \& Tabak, I. (2014). Scaffolding. In R. K. Sawyer, The Cambridge Handbook of the Learning Sciences (pp. 44-62). New York: Cambridge University Press.

Ritten, J. M., Boone, W. J. \& Rubba, P. A. (2001). Development of an Instrument to Assess Prospective Elementary Teacher Self-Efficacy Beliefs about Equitable Science Teaching and Learning . Journal of Science Teacher Education, 175-198.

Scunk, D. H. (1985). Self Efficacy and Classroom Learning. Psychology in the Schools, 208-223.

Willemsen, E. W. \& Gainen, J. (1995). Reenvisioning Statistics: A Cognitive Apprenticeship Approach. New Direction for Teachin and Learning, 99-108.

Wolf, K. N. (1997). Predicting Positive Self-Efficacy in Group Problem Solving. Human Resource Development Quarterly, 155-169.

Wood, R. E. \& Locke, E. E. (1987). Self-efficacy: Implications for organizational behavior and human resource management. Academy of Management Review, 12, 472-485.

Zhao, H., Seibert, S. E. \& Hills, G. E. (2005). The Mediating Role of Self-Efficacy in the Development of Entrepreneurial Intentions. Journal of Applied Psychology, 90(6), 1265-1272. 